\title{
FOREIGN CORRUPT PRACTICES - THE GROWTH AND LIMITATIONS OF CANADIAN ENFORCEMENT ACTIVITY
}

\author{
Neil Campbell, Elisabeth Preston \& Jonathan O’Hara* \\ INTRODUCTION
}

Canada's foreign corruption avoidance legislation is the Corruption of Foreign Public Officials Act ("CFPOA"). ${ }^{1}$ The CFPOA was enacted in 1999, more than two decades after the path-breaking US Foreign Corrupt Practices Act ("FCPA") ${ }^{2}$ and over a decade before the United Kingdom brought into force the Bribery Act 2010 ("UK Bribery Act"). ${ }^{3}$ While Canadian enforcement activity initially was slow to materialize, it is now accelerating.

The CFPOA is deliberately similar in many ways to the US FCPA. This allows the many Canadian businesses with US operations (and vice versa) to have compatible cross-border compliance programs. However, two key limitations set the Canadian regime apart from its southern neighbor. The CFPOA does not assert jurisdiction over acts of corruption committed entirely outside of Canada, and the CFPOA appears not to apply to the non-profit sector. Aside from these two areas, the CFPOA is a robust regime which necessitates careful compliance activity by Canadian companies and individuals carrying on business abroad.

\section{DEVELOPMENT OF THE CANADIAN LEGISLATION}

The CFPOA was enacted in response to the Organization for Economic Cooperation and Development's anti-bribery convention ("OECD Convention"). ${ }^{4}$ Canada signed the OECD Convention in late 1997 and ratified it in late 1998.5

* Neil Campbell is a partner in the Toronto office of McMillan LLP. Elisabeth Preston is a partner and Jonathan O'Hara is an associate in the Ottawa office of McMillan LLP.

1. Corruption of Foreign Public Officials Act, S.C. 1998, c. 34 (Can.) [hereinafter CFPOA].

2. Foreign Corrupt Practices Act of 1977,15 U.S.C. $\$ \S 78 \mathrm{~m}, 78 \mathrm{dd}-1$ et seq., $78 \mathrm{ff}$ (1998) [hereinafter FCPA].

3. Bribery Act 2010, 2010, c. 23 (U.K.) [hereinafter UK Bribery Act].

4. Organization for Economic Co-operation and Development, Convention on Combating Bribery of Foreign Public Officials in International Business Transactions, OECD DAFFE/IME/BR(97)20, Dec. 17, 1997, 337 I.L.M. 9 [hereinafter OECD Convention].

5. Department of Justice- Canada, The Corruption of Foreign Public Officials ACT: A GuIDE, 1 - 2 (May 1999), available at http://www.justice.gc.ca/eng/dept-min/pub/ cfpoa-lcape/index.html [hereinafter DOJ Guide]. 
Canada is also a party to the Inter-American Convention Against Corruption $^{6}$ but did not sign it until mid-1999 and ratified it in mid-2000. ${ }^{7}$ Canada signed the United Nations Convention Against Corruption ${ }^{8}$ in mid2004 and ratified it in late $2007 .{ }^{9}$ Canada did not make any changes to the CFPOA in order to comply with either of these two conventions, likely because these conventions generally are less onerous than the OECD Convention. Thus, the OECD Convention has been the primary international instrument driving Canada's foreign corruption avoidance regime.

\section{OVERVIEW OF THE CFPOA REGIME}

Consistent with the OECD Convention, the CFPOA seeks to curtail corrupt practices by Canadians and Canadian businesses operating abroad. More specifically, it focuses on acts of bribery or similar activities geared toward securing advantages in return for such activities. The core bribery offense in the CFPOA is prescribed in section 3 (which is very similar to both the FCPA and the OECD Convention): ${ }^{10}$

3. (1) Every person commits an offence who, in order to obtain or retain an advantage in the course of business, directly or indirectly gives, offers or agrees to give or offer a loan, reward, advantage or benefit of any kind to a foreign public official or to any person for the benefit of a foreign public official

(a) as consideration for an act or omission by the official in connection with the performance of the official's duties or functions; or

(b) to induce the official to use his or her position to influence any acts or decisions of the foreign state or public international organization for which the official performs duties or functions.

6. Organization of American States, Inter-American Convention Against Corruption, Mar. 29, 1996, 35 I.L.M 724 [hereinafter Inter-American Convention].

7. Signatures and Ratifications B-58: Inter-American Convention Against Corruption, Organization of American States, http://www.oas.org/juridico/english/sigs/b-58.html (last visited Feb. 5, 2013).

8. United Nations Convention Against Corruption, G.A. Res. 58/4, Annex, U.N. Doc A/RES/58/4 (Oct. 31, 2003), available at http://unpan1.un.org/intradoc/groups/public/ documents/un/unpan038988.pdf [hereinafter UN Convention].

9. Signatory and Ratification Status for United Nations Convention against Comuption, UNITED NATIONS TREATY COLLECTION, http:/treaties.un.org/Pages/ViewDetails.aspx?src=IND\& mtdsg_no=XVIII-14\&chapter=18\&lang-en (last visited Feb. 5, 2013).

10. Cf. FCPA, supra note 2, $\S \S 78 \mathrm{dd}-1(\mathrm{a})-2(\mathrm{a}), 3(\mathrm{a})$; $c f$. OECD Convention, supra note 4 , art. $1, \mathbb{1} 1$. 
(2) Every person who contravenes subsection (1) is guilty of an indictable offence and liable to imprisonment for a term not exceeding five years."

While the CFPOA does not refer to monetary penalties, it does specify that bribery is an indictable offense rather than a summary conviction offense. The Criminal Code provides that, for indictable offenses where the offense provision does not specify a maximum, the fine for a convicted corporation is at the discretion of the Court. ${ }^{12}$ This means that there is no maximum monetary penalty to the amount a corporation could be fined when convicted of the foreign bribery offense. ${ }^{13}$

\section{ENFORCEMENT ACTIVITY}

The history of prosecutions under the CFPOA is limited and recent. The federal government reported in 2011 that two prosecutions (both successful) have been completed to date. ${ }^{14}$ Charges have been laid in a third case and Canada has approximately twenty additional foreign corruption investigations underway. ${ }^{15}$

\section{The Hydro Kleen Case}

In Canada's first prosecution under the CFPOA, Hydro Kleen Systems Inc. (Hydro Kleen) pleaded guilty to making various bribery payments to a senior US immigration inspector employed at the Calgary International Airport. ${ }^{16}$

The inspector, unbeknownst to his government employer, had set up a consulting business on the side. ${ }^{17}$ In his capacity as a consultant, the inspector advised Hydro Kleen on the best ways for their employees to enter the United States on work visas by explaining what to say to immigration officials when asked, and drafting letters and documents required to enter the United States. ${ }^{18}$ One of Hydro Kleen's competitors,

11. CFPOA, supra note $1, \S 3$.

12. Criminal Code, R.S.C. 1985 , c. C-46, $\$ 735(1)$ (a) (Can.) [hereinafter Criminal Code].

13. CFPOA, supra note 1 .

14. Corporate Social Responsibility - Bribery and Corruption, The Twelfth Annual Report to Parliament, Foreign Affairs and International Trade Canada (Oct. 17, 2011) http://www.international.gc.ca/trade-agreements-accords-commerciaux/ds/12-reportrapport.aspx?view=d [hereinafter 12th Report to Parliament]; See also Her Majesty the Queen v. Griffiths Energy International (2013), E-File No.:CCQ13GRIFFITHSENER, Action No. 130057425Q1, (Can. Alta. Q.B.).

15. Id.

16. Id.

17. R. v. Watts, [2005] A.J. 568, para. 48 (Can. Alta. Q.B.).

18. Id. at paras. 56-57. 
which did not experience the same level of success in bringing its employees across the border, hired a private investigator who directly observed an incident where a manager at Hydro Kleen handed over an envelope to the US inspector in return for another envelope. ${ }^{19}$

A subsequent Royal Canadian Mounted Police ("RCMP") investigation led to charges against Hydro Kleen, its president, and an employee. ${ }^{20}$ It was determined that Hydro Kleen had paid $\mathrm{C} \$ 28,300$ in bribes. ${ }^{21}$ Hydro Kleen pleaded guilty to one count of bribery, contrary to section 3(1)(a) of the CFPOA. ${ }^{22}$ The other charges were stayed. Hydro Kleen paid a fine of $C \$ 25,000$ (i.e. $88 \%$ of the improper payments). ${ }^{23}$

In the course of accepting the sentence recommended by the prosecution and defense counsel, Justice Sirrs highlighted the international implications of corrupt behavior:

Where someone is dealing in international trade, especially with the United States, who is our closest and most important trading partner, matters that involve corruption that might interfere with trade are of much importance to Alberta. . . . [It is important] that trade with the United States be seen to be honest and of high ethical standards in order to avoid further complications that affect people that maybe are not even in the oil industry, because of the fact of our reputations gained concerning the business practices of Albertans. ${ }^{24}$

Justice Sirrs also described the fine as "significant" and accepted it after noting that a guilty plea was entered and responsibility was accepted, ${ }^{25}$ both of which are mitigating factors in sentencing for criminal offenses given the sentencing objectives in the Criminal Code. ${ }^{26}$

It is ironic that the country whose official was involved in Canada's first conviction is Canada's largest trading partner and the jurisdiction which has led the development of foreign corrupt practices enforcement. In rankings published by Transparency International, a non-profit organization

19. David Elzinga, A Steep Price, CA MagazINE, (Nov. 2010), available at http://www.camagazine.com/archives/print-edition/2010/nov/regulars/camagazine43455.aspx.

20. Id.

21. R. v. Watts, at para. 20.

22. Id. at paras. 20-21.

23. 12th Report to Parliament, supra note 14. The US inspector was convicted of accepting secret commissions contrary to section 426(1)(a)(ii) of the Criminal Code and was sentenced to six months in prison and then deported to the United States. Id.

24. R. v. Watts, at paras. 181-82.

25. See id. at paras. $184,188$.

26. Criminal Code, supra note 12 , at $718(\mathrm{f})$. 
that seeks to reduce corruption, the United States is ranked 19th with a score of $73 .{ }^{27}$ Canada, in comparison, is currently ranked 9th with a score of $84{ }^{28}$

\section{The Niko Resources Case}

The second prosecution under the CFPOA was also resolved with a guilty plea. The magnitude of the bribe was somewhat larger, but the penalty was much more substantial.

In 2005, an explosion at a gas field in Bangladesh owned by Niko Resource (Niko) caused local villagers to call for compensation. ${ }^{29}$ In order to minimize the amount ordered for compensation, two Niko representatives delivered a $\mathrm{C} \$ 190,000$ Toyota Land Cruiser to Energy Minister A.K.M. Mosharraf Hossain, the official largely responsible for handling the matter in the Bangladesh government. ${ }^{30}$

After a lengthy investigation, the RCMP laid charges and Niko agreed to plead guilty. ${ }^{31}$ The prosecutor and Niko's counsel recommended that the court impose a total fine of $C \$ 9,499,000(5,000 \%$ of the value of the bribe), which was accepted as an appropriate sentence. ${ }^{32}$ Niko was also given probationary terms for three years. ${ }^{33}$

At the sentencing hearing, Justice Brooker remarked upon the seriousness of the behavior from a public perspective saying bribery "tarnishes the reputation of Alberta and of Canada [and] ... is an embarrassment to all Canadians. . . . [T]he fact that a Calgaryheadquartered oil and gas company has bribed a foreign government official is a dark stain on Calgary's proud reputation as the energy capital of Canada." 34

In addition, the prosecutors submitted cases under the US FCPA as sentencing precedents, and these were given consideration by the Court. ${ }^{35}$

27. Transparency InT'L, Corruption PerCePTiOns IndeX 2012 2, 3 (2012) (noting the lowest ranking is 174th, occupied by Somalia, North Korea, and Afghanistan, each with a score of 8), available at http://www.transparency.org/cpi2012/results [hereinafter Tl CORRUPTION INDEX].

28. Id.

29. John W. Boscariol, a Deeper Dive Into Canada's First Significant Foreign Bribery Case: Niko Resources, (McCarthy Tetrault LLP Publications, Nov. 2011), available at http://www.mccarthy.ca/article_detail.aspx?id=5640.

30. 12th Report to Parliament, supra note 14, at 5. Bangladesh has a TI Corruption Index rating of 26, resulting in a rank of 144th. TI Corruption Index, supra note 27.

31. R. v. Niko Resources Ltd. (2011), E-File No.: CCQ11NIKORESOURCES, ๆๆ 64-66 (Can. Alta. Q.B.).

32. BOSCARIOL, supra note 29, at 4.

33. R. v. Niko Resources Ltd. (2011) ๆ 64.

34. BOSCARIOL, supra note 29 , at 4 .

35. Id. 
While Canada had received criticism about weak enforcement activity, the Niko case sends a clear signal that the Canadian authorities are prepared to bring proceedings and obtain meaningful penalties.

\section{The Karigar Case}

The Canadian authorities have charged Nazir Karigar under the CFPOA in respect of his efforts to obtain a security equipment contract with Air India worth $C \$ 100,000,000$ in $2005 .^{36}$ Karigar allegedly gave $\mathrm{C} \$ 250,000$ to a political associate of the Indian Civil Aviation Minister, Praful Patel. ${ }^{37}$ Air India eventually backed out of its plans to buy the equipment. Mr. Patel has denied any wrongdoing, as has Mr. Karigar. ${ }^{38}$

A high-profile prosecution is currently in progress. At this stage only limited details are publicly available based on recent media reports. ${ }^{39}$ The preliminary hearing took place in September $2012 .{ }^{40}$ Karigar is defending in part on the basis of a jurisdictional argument. ${ }^{41}$ The case can be expected to generate important jurisprudence on this point and potentially on the application of the CFPOA to individuals, including the approach to penalties.

\section{Investigations Related to SNC-Lavalin}

The Canadian authorities usually keep CFPOA investigations confidential until charges are laid. However, targets may make disclosures related to investigations in order to comply with securities law requirements. For example, in September 2011, SNC-Lavalin confirmed media reports that it was the subject of a CFPOA investigation related to a US $\$ 1,200,000,000$ World Bank bridge project in Bangladesh. ${ }^{42}$ Recent

36. Greg McArthur et al., Canadian Accused of Bribing Cabinet Minister in India Is a Test Case for Canada's Foreign Anti-Corruption Law, THE GLOBE AND MAIL (Sept. 6, 2012), http://m.theglobeandmail.com/news/politics/canadian-accused-of-bribing-cabinetminister-in-india/article2323342/.

37. Id. (India has a TI Corruption Index rating of 36 , resulting in a rank of 94 th. TI Corruption Index, supra note 27, at 7.)

38. McArthur, supra note 36.

39. Id.

40. Id.

41. Id. Closing arguments are expected to begin in March 2013. See David MarTin \& CASEY LegGeT, F'oreign CORRUPT PRACTICES:Issues AND DEVElopMENTS IN THE CANADIAN CONTEXT (2013), available at http://martinandassociates.ca/wp-content/uploads/ 2013/02/Foreign-Corrupt-Practice-Issues-and-Developments-in-the-Canadian-Context.pdf.

42. See Press Release, SNC-Lavalin, Clarification on the RCMP Investigation (Sept. 6 2011), available at http://www.snclavalin.com/news.php?lang=en\&id=1527\&action=press release_details\&paging=1\&current \%E2\%80\%A6; see also Andrea Shalal-Esa \& Tim Ahmann, Canadian Authorities Probing Employees of SNCLavalin 
media reports indicated two new developments: that RCMP investigators would arrive in Bangladesh sometime in late June 2012 to share and collect more information from the anti-corruption commission in Bangladesh, ${ }^{43}$ and that two former SNC-Lavalin executives would be tried on corruption charges in $2013 .^{44}$

There is also a separate investigation of SNC-Lavalin by authorities in India in relation to alleged bribery involving the Power Minister and other officials in India's Kerala state in 1997, but this appears to pre-date the enactment of the CFPOA and there has not been any confirmation of a parallel Canadian investigation. ${ }^{45}$ More recently, in February 2012, SNCLavalin disclosed that it was conducting an internal investigation into $\mathrm{C} \$ 35,000,000$ of unexplained payments, but the company has not confirmed whether this involves potential foreign corruption issues and/or the company's widely-publicized relationship with the son of former Libyan leader, Moammar Gadhafi. ${ }^{46}$ By June 2012, the unexplained amount had risen to $C \$ 56,000,000 .^{47}$ Although a shareholder suit was filed in May, two former employees whom the company blames for the missing millions could not be served: Riadh Ben Aissa (jailed in Switzerland) and Stephane Roy (not locatable). ${ }^{48}$

Group (Sept. 2, 2011), http://www.reuters.com/article/2011/09/03/us-worldbank-canadaidUSTRE78206C20110903.

43. The Canadian Press, SNC-Lavalin Accused of Offering Bribes to Six Bangladeshi Officials: Report (June 21, 2012), available at retasite.files.wordpress.com/2012/06/retacanadian-press-art-june-21-2012.pdf.

44. The Canadian Press, Ex-SNC Lavalin Executives to Face Corruption Charge in Court Next Year, FinanCIal Post, (June 25, 2012), http://business.financialpost.com/ 2012/06/25/ex-snc-lavalin-executives-to-face-corruption-charge-in-court-next-year/. The preliminary hearing for the two executives, Ramesh Shah, former VP, and Mohammad Ismail, former director of international projects, is set for April 8-19,2013. Id.

45. See SNC-Lavalin Deny Bribing Kerala Politicians, THE New INDIAN EXPRESS, (June 12, 2009), http://newindianexpress.com/states/kerala/article106707.ece.

46. See Press Release, SNC-Lavalin, SNC-Lavalin Provides Update on Announcement of 2011 Financial Results and Impact on 2011 Outlook (Feb. 28, 2012), www.snclavalin.com/news.php?lang=en\&id $=1685$ \&action=press_release_details\&paging $=1$ \&start=26; see also Paul Waldie, SNC-Lavalin Probes Mystery Payments GloBE \& MAIL, (Feb. 28, 2012), http://www.theglobeandmail.com/globe-investor/snc-lavalin-probes-mysterypayments/article $533489 \%$.

47. Stewart Bell \& Adrian Humphreys, Lawsuit against Former SNC-Lavalin Executives Linked to Gaddafi Escape Plot Can Continue: Judge, NATIONAL Post, (June 28 2012), http://news.nationalpost.com/2012/06/28/lawsuit-against-former-snc-lavalin-executiveslinked-to-gaddafi-escape-plot-can-continue-judge/.

48. Id. Two former executives allegedly were also responsible for awarding a contract to Cynthia Vanier, who was subsequently arrested in Mexico for allegedly trying to smuggle Gaddafi's son Saadi to Mexico. Id. On July 17, 2012, the Canada Border Services Agency said it was taking steps to deport an Australian private security contractor, Gary Peters, who had ties to Gadhafi and Ms. Vanier. Mr. Peters has told reporters that he helped members of the Gaddafi family escape Libya, and his testimony forms part of the evidence against Ms. Vanier. See also Security Contractor with Gaddafi Ties to Face Deportation Hearing, 


\section{Future Enforcement Activity}

We expect that there will be an increasing flow of prosecutions under the CFPOA. In part, this is a reflection of the existing pipeline of investigations and the profile of the Karigar and SNC-Lavalin matters. ${ }^{49}$ More generally, there is regular media and public sensitivity about corporate wrongdoing. While controversial proposals to make Canadian companies subject to domestic review in respect to their overseas environmental and human rights practices were not enacted in the prior Parliament, ${ }^{50}$ the present Conservative Government has passed legislation requiring minimum mandatory sentencing for fraud over $C \$ 1,000,000,{ }^{51}$ and it used the Parliamentary majority it obtained in 2011 to push through "tough on crime" reforms ${ }^{52}$ which include mandatory jail time for some white collar as well as other crimes, when a custodial sentence is imposed. ${ }^{53}$

Canada's international policy interests point in the same direction. For example, the Canadian Government is seeking to expand trade and investment links with China (including a bilateral investment treaty awaiting ratification ${ }^{54}$ ), India (including a bilateral trade agreement awaiting ratification ${ }^{55}$ and free trade agreement negotiations ${ }^{56}$ ), Asia more generally (e.g. joining the Trans-Pacific Partnership negotiations ${ }^{57}$ ), and Europe (free

NATIONAL POST (July 17, 2012), http://news.nationalpost.com/2012/07/17/security-contractorwith-gaddafi-ties-to-face-deportation-hearing/.

49. See generally 12th Report to Parliament, supra note 14.

50. See generally Canada, Bill C-300, An Act Respecting Corporate Accountability for the Activities of Mining, Oil or Gas in Developing Countries, 2nd Session, 40th Parliament, 57-58 Elizabeth II, 2009 (first reading Feb. 9, 2009).

51. Standing up for Victims of White Collar Crime Act, S.C. 2011, c. 6, s. 2 (Can.) (amending s. 380 of the Criminal Code). The Ontario Court of Appeal has also recently issued an important decision which signals that substantial prison terms are normally appropriate in commercial fraud cases. See R. v. Drabinsky (2011), 2011 O.A.C. 582, at paras. 157-60 (Can. Ont. C.A.).

52. See generally An Act to Enact the Justice for Victims of Terrorism Act and to Amend the State Immunity Act, the Criminal Code, the Controlled Drugs and Substances Act, the Corrections and Conditional Release Act, the Youth Criminal Justice Act, the Immigration and Refugee Protection Act and Other Acts, S.C. 2011-2012, c. 10 (Can.).

53. Id.

54. See Background on the Canada-China Foreign Investment Promotion and Protection Agreement Negotiations (FIPA), ForeIGn AFFaIRS AND INTERnational TRADE CANADA, http://www.international.gc.ca/trade-agreements-accords-commerciaux/agr-acc/ fipa-apie/china-chine.aspx?lang=eng\&view=d (last modified Nov. 30, 2012).

55. See Canada-India Foreign Investment Promotion and Protection Agreement (FIPA) Negotiations, Foreign AFFaIRS AND INTERNATIONAL Trade CANADA, http://www.international.gc.ca/trade-agreements-accords-commerciaux/agr-acc/fipa-apie/ indiainde.aspx?lang=eng\&view=d (last modified Nov. 7, 2012).

56. See Canada-India Free Trade Agreement Negotiations, ForeIGN AFFAIRS AND INTERNATIONAL TRADE CANADA, http://www.international.gc.ca/trade-agreements-accordscommerciaux/agr-acc/india-inde.aspx?view=d (last modified Dec. 18, 2012).

57. See, e.g. Minister Fast Highlights Prosperity-Generating Benefits of Canada's 
trade agreement negotiations ${ }^{58}$ ). We expect that Canada's level of commitment to foreign corrupt practices enforcement is likely to be of increasing interest to OECD members and other countries whose companies will be competing for business opportunities with Canadian multinationals.

The importance of foreign corrupt practices enforcement is receiving widespread visibility through record-breaking US fines against companies such as Siemens (US\$800,000,000), Halliburton/KBR (US\$57,000,000), BAE Systems (US $\$ 400,000,000$ ), and others. ${ }^{59}$ The vigorous UK Bribery Act 2010, which covers facilitating payments ${ }^{60}$ (that are subject to exceptions in the CFPOA, ${ }^{61}$ FCPA $^{62}$ and OECD Convention ${ }^{63}$ ) and which, under many circumstances, applies to the activities of non-UK affiliates, ${ }^{64}$ has further heightened the attention on foreign corrupt practices. These developments can be expected to provide incentives to the Canadian Government to demonstrate that the CFPOA is being enforced diligently. However, there are two areas where the scope of Canadian law has important gaps.

\section{THE LIMITED JURISDICTIONAL BASIS OF THE CFPOA}

Foreign corrupt practices inherently involve cross-border activity. There are two main bases for countries to establish jurisdiction over offenses in this area: territoriality and nationality. As a general matter,

Inclusion in Trans-Pacific Partnership Talks, Foreign AfFaIRS AND INTERnational Trade CANADA, http://www.international.gc.ca/media_commerce/comm/news-communiques/2012/ 05/03a.aspx?lang=eng\&view $=\mathrm{d}$ (last modified May 4, 2012); e.g., Trans-Pacific Partners Invite Canada to the Table, Canada to Join Trade Talks with Asia-Pacific Nations, CBC NEws, http://www.cbc.ca/news/politics/story/2012/06/19/pol-g20-harper-obama-tpp-mexico.html (last updated June 19, 2012, 1:37 PM ET).

58. Canada-EU Trade Agreements, Opening New Markets in Europe, FoREIGN AFFAIRS AND INTERNATIONAL TRADE CANADA, http://www.international.gc.ca/trade-agreementsaccords-commerciaux/agr-acc/eu-ue/can-eu.aspx?view=d (last modified Jan. 15, 2013).

59. See, e.g. Joe Palazzolo, Another US Company Bumped off FCPA Top 10 List, WaLL ST. J. BLOG (Apr. 6, 2011, 4:37 PM) http://blogs.wsj.com/corruption-currents/2011/ 04/06/another-us-company-bumped-off-fcpa-top-10-list/. It should be noted that US pleas may cover securities law or other violations in addition to $F C P A$ offenses.

60. United KINGDOM MinistRy OF JUSTICE, THE BRIBERY ACt 2010 - GUIDANCE about Procedures Which Relevant Commercial Organizations Can Put into Place to Prevent Persons Associated With Them from Bribing (2010), at paras. 44-45, available at http://www.justice.gov.uk/downloads/guidance/making-reviewing-law/bribery-act-2010guidance.pdf.

61. CFPOA, supra note $1, \S 3(4)$.

62. See generally FCPA, supra note 2.

63. Organization for Economic Co-operation and Development (OECD), Commentaries on the Convention on Combating Bribery of Foreign Public Officials in International Business Transactions, at para. 9 (1997) (adopted by the Negotiating Conference on Nov. 21, 1997).

64. See generally UK Bribery Act, supra note $3, \S 6$ (the UK Bribery Act broadly defines "associated person"). 
common law countries including Canada, ${ }^{65}$ tend to use the territoriality principle as a primary basis for jurisdiction ${ }^{66}$ in most areas of law. ${ }^{67}$ In contrast, civil law countries are much more likely to apply their laws to acts of their nationals which occur outside their borders. ${ }^{68}$

Canada only asserts jurisdiction over foreign corruption offenses on the basis of territoriality - i.e. conduct which occurs in whole or in part within Canadian borders. ${ }^{69}$ Unlike many other jurisdictions, it does not assert jurisdiction over Canadian nationals when they are acting entirely outside Canada. ${ }^{70}$

In contrast, the FCPA asserts jurisdiction over "domestic concerns", which include but are not limited to US nationals acting outside the country:

(1) The term "domestic concern" means--

(A) any individual who is a citizen, national, or resident of the United States; and

(B) any corporation, partnership, association, jointstock company, business trust, unincorporated organization, or sole proprietorship which has its principal place of business in the United States, or which is organized under the laws of a State of the United States or a territory, possession, or commonwealth of the United States. ${ }^{71}$

65. Canada is predominantly a common law jurisdiction, except for the province of Quebec, whose local laws are based on a civil law system. See Canada's System of Justice: Where Our Legal System Comes from, DEP'T OF JUSTICE, http://www.justice.gc.ca/eng/dept$\mathrm{min} /$ pub/just/03.html (last modified Mar. 8, 2012).

66. In this context, jurisdiction refers to the legal competence to make laws governing a particular topic, commonly known as "prescriptive jurisdiction"; this is distinguished from "enforcement jurisdiction"- the circumstances under which a state has the legal competence to enforce its laws against an individual or an entity. See generally JOHN CURRIE, PUBLIC INTERNATIONAL LAW 332-352 ( $2 \mathrm{~d}$ ed. 2008). See also an early articulation of the differences between these two aspects of jurisdiction in The Case of the SS "Lotus" (Fr. v. Turk.) (1927), P.C.I.J. (Ser. A) No. 10, paras. 45-46, available at http://www.worldcourts.com/ pcij/eng/decisions/1927.09.07_lotus.htm.

67. See, e.g. CEDRIC RYNGAERT, JURISDICTION IN INTERNATIONAL LAW $42-84$ (2008).

68. Id.

69. See, e.g. A. Timothy Martin, Canadian Law on Corruption of Foreign Public Officials, 10 NAT'L J. CONST. L. 189, 193 (1999).

70. There are other principles under which states may claim jurisdiction in respect of international matters such as where a state's nationals are injured or where the state's interests are affected. These other principles will not be addressed in this paper because they have not generally been applied as a basis for asserting jurisdiction over foreign corruption offenses.

71. FCPA, supra note $2, \S 78 \mathrm{dd}-2(\mathrm{~h})$. 
Similarly, the United Kingdom asserts jurisdiction over bribery offenses committed by its nationals occurring outside UK territory. Sections 12(2) and (3) of the UK Bribery Act together stipulate that if a bribery offense occurs outside of the United Kingdom, and the person has a close connection with the United Kingdom, then proceedings can be commenced in any part of the United Kingdom. "Close connection" is defined as a British citizen, a body incorporated under the law of any part of the United Kingdom, or various other analogous situations. ${ }^{73}$

\section{Canada's liberal approach to jurisdiction on a territorial basis}

The primary basis for Canada's approach to criminal law jurisdiction generally is the "territorial principle." ${ }^{, 74}$ This stems from the notion that a state has sovereign jurisdiction over all matters occurring within its borders. Canada's general preference for the territorial approach is demonstrated in two statutes. First, Canada's federal Interpretation Act states that: "Every enactment applies to the whole of Canada, unless a contrary intention is expressed in the enactment." ${ }^{\text {75 }}$ Second, and more specifically applicable to the CFPOA, is the Criminal Code, which governs all criminal offenses except to the extent provided in other legislation. It expresses the default position that Canada will not assert jurisdiction over an offense which occurs outside Canada. It states, in part, "Subject to this Act or any other Act of Parliament, no person shall be convicted or discharged under section 730 of an offence committed outside Canada." ${ }^{, 76}$

These provisions do not mean that the Canadian authorities can only prosecute offenses which were wholly committed inside Canada. The courts have interpreted territoriality more broadly to encompass activity that has a real and substantial connection to Canadian territory. In Libman, ${ }^{77}$ Justice La Forest of the Supreme Court of Canada, speaking for the whole Court, held:

I might summarize my approach to the limits of territoriality in this way. As I see it, all that is necessary to make an offence subject to the jurisdiction of our courts is that a significant portion of the activities constituting that offence took place in Canada. As it is put by modern

72. UK Bribery Act, supra note $3, \S 12$ (2) - (3).

73. Id., 12(4) and 8(1).

74. CURRIE, supra note 66 , at 341 .

75. Interpretation Act, R.S.C. 1985 , c. I-21.

76. Criminal Code, supra note 12, at 6(2). The reference to "discharge" refers to absolute or conditional discharges, both of which are provided for in $\$ 730$ of the Criminal Code and would constitute forms of sanction in relation to an offense.

77. Libman v. The Queen, [1985] 2 S.C.R. 178 (Can.). 
academics, it is sufficient that there be a "real and substantial link" between an offence and this country. ${ }^{78}$

The Libman test can result in a reasonably expansive approach to territoriality. A sufficient connection to Canada may exist where part of the offense occurred in Canada, even though other important parts did not. For example, a sufficient connection for the offense of murder was found where one Canadian assaulted another Canadian in the Dominican Republic, and the victim died (an important element of the offense) after returning to Canada ${ }^{79}$ Similarly, the Competition Bureau regularly asserts jurisdiction over international cartels that involve direct or even indirect sales to Canadian customers on the basis that such transactions have a real and substantial link to Canada; Canadian courts have accepted numerous guilty pleas on this basis. ${ }^{80}$

With respect to corruption of foreign officials, neither the CFPOA nor any other Act of Parliament contains a contrary provision which would displace section 6(2) of the Criminal Code. Thus the "real and substantial link" jurisprudence applies to the CFPOA. However, as discussed more fully below, this test may not reach bribery that occurs entirely or predominantly outside of Canada. The charge in the Karigar case (noted above) was challenged in a motion filed on April 30,2012, on the grounds that the Canadian courts lack jurisdiction ${ }^{81}$ This challenge may clarify what constitutes a "real and substantial link" in the case of a foreign corruption charge.

Canada's assertion of nationality-based jurisdiction for certain other offenses

It is accepted at international law that a state can assert jurisdiction over the acts of its nationals, wherever those nationals may be. The basis for this type of jurisdiction is commonly known as the "nationality principle."

Canada exceptionally asserts jurisdiction on a basis other than territoriality. Most notably, Section 7 of the Criminal Code establishes jurisdiction to prosecute certain offenses even where there is no territorial

78. Id. at para. 74 .

79. R. v. Ouellette, 126 C.C.C. (3d) 219 (Que. Sup. Ct. 1998).

80. See, e.g., J. William ROWLEY \& A. NEIL CAMPBELL, JURISDICTION AND Litigation Developments In Canadian Competition Law 2-4, (New York State Bar Association Antitrust Committee Meeting, Oct. 6, 2004) (2004).

81. Shannon Kari, Threshold of Anti-corruption Law Tested, THE LAWYER's WEEK (Apr. 27, 2012), http://www.lawyersweekly-digital.com/lawyersweekly/3148?pg=4\#pg4. See also MARTIN \& LEGGET, supra note 41.

82. CURRIE, supra note 66 , at 345 . 
basis. ${ }^{83}$ Most of the offenses listed in Section 7 can be prosecuted based on the nationality theory of jurisdiction including child sex tourism, terrorism, torture, crimes against internationally protected persons, hostage taking, and offenses relating to nuclear material. ${ }^{84}$ War crimes and crimes against humanity can also be prosecuted on the basis of a nationality theory of jurisdiction. $^{85}$

\section{Canada's international obligations regarding jurisdiction over foreign corruption offenses}

Canada is required by the OECD Convention to take jurisdiction over foreign corruption offenses that occur wholly or partially in its territory. ${ }^{86}$ Similarly, Canada is required by the UN Convention to take jurisdiction over foreign corruption offenses that occur with its territory. ${ }^{87}$ The InterAmerican Convention has the same type of jurisdiction requirement regarding offenses committed in a party's territory. ${ }^{88}$ Canada's liberal application of the territoriality principle using the real and substantial link standard meets these obligations.

The UN Convention also requires Canada to assert jurisdiction over corruption offenses which occur onboard a Canadian flagged vessel or on an aircraft registered under Canadian law. ${ }^{89}$ The Criminal Code provides for Canadian jurisdiction over offenses committed on Canadian ships and aircraft. ${ }^{90}$ The assertion of Canadian jurisdiction beyond a purely territorial basis in these contexts is consistent with the UN Convention requirements.

The OECD Convention contains a second jurisdictional requirement, which relates to nationality. It states, in part: "Each Party which has jurisdiction to prosecute its nationals for offences committed abroad shall take such measures as may be necessary to establish its jurisdiction to do so in respect of the bribery of a foreign public official, according to the same principles." ${ }^{.91}$

83. Criminal Code, supra note 12 , at 7.

84. Id. at 7(3) - (4.1).

85. Crimes Against Humanity and War Crimes Act, S.C. 2000, c. 24, §8(a)(i).

86. OECD Convention, supra note 4, art. 4(1).

87. UN Convention, supra note 8 , art. 42(1)(a).

88. Inter-American Convention, supra note 6 , art. V(2).

89. UN Convention, supra note 8 , art. 42(1)(b).

90. Criminal Code, supra note 12 at $7(2.1) \& 2.2$ (ships), 7 (1) \& (2) (aircraft).

91. OECD Convention, supra note 4, at 4(2). The Inter-American Convention also seems to impose a nationality requirement on parties, but its text and context (i.e. not being in Article V (Jurisdiction)) make the requirement's application to Canada less clear than the OECD Convention requirement. Article VIII of the Inter-American Convention states, "Subject to its Constitution and the fundamental principles of its legal system, each State Party shall prohibit and punish the offering or granting, directly or indirectly, by its nationals, persons having their habitual residence in its territory, and businesses domiciled 
Immediately after the CFPOA was enacted, Canada's apparent noncompliance with this aspect of the OECD Convention was identified. ${ }^{92}$ The OECD Working Group on Bribery in International Business Transactions ("OECD Working Group") ${ }^{93}$ has performed three reviews of the Canadian implementation of the OECD Convention, ${ }^{94}$ each of which has criticized Canada's decision not to assert jurisdiction on a nationality basis. ${ }^{95}$

\section{The 1999 OECD Report}

The OECD's first review of the CFPOA in 1999 stated: "Canada explained that territorial jurisdiction is very broadly interpreted by Canadian courts and, in its opinion, that it is a very effective basis of jurisdiction. Some concerns were expressed that Canada's decision not to assert nationality jurisdiction could create a gap in the coverage of its implementing legislation." ${ }^{.96}$

During the investigation that preceded this first report, Canada cited three then-recent cases in other areas of law in support of the argument that Canada has an effective basis to prosecute foreign corruption offenses because of the broad interpretation Canada takes to territorial jurisdiction. ${ }^{97}$

there, to a government official of another State..." Inter-American Convention, supra note 6, at art.VIII.

92. See, e.g., Martin, supra note 69.

93. The OECD Working Group, which is supported by the OECD's Directorate for Financial and Enterprise Affairs, periodically reviews foreign corrupt practices enforcement in its member states. See, OECD Working Group on Bribery in International Business Transactions, OECD: BETTER POLICIES FOR BETTER LIVES http:/www.oecd.org/ investment/briberyininternationalbusiness/anti-briberyconvention/

oecdworkinggrouponbriberyininternationalbusinesstransactions.htm (last visited Feb. 5, 2013).

94. OECD, CANADA - REVIEW OF IMPLEMENTATION OF THE CONVENTION AND 1997 RECOMMENDATION (July 1999), available at http://www.oecd.org/dataoecd/13/35/ 2385703.pdf [hereinafter 1999 OECD REPORT]; OECD, CANADA - PHASE 2: REPORT ON THE APPLICATION OF THE CONVENTION ON COMBATING BRIBERY OF ForEIGN PUBLIC OfFICIALS IN INTERNATIONAL BUSINESS TRANSACTIONS AND THE 1997 RECOMMENDATION OF COMBATING BRIBERY IN INTERNATIONAL BUSINESS (Mar. 2004), available at http://www.oecd.org/ dataoecd/20/50/31643002.pdf [hereinafter 2004 OECD REPORT]; OECD, CANADA - PHASE 3: REPORT ON THE APPLICATION OF THE CONVENTION ON COMBATING BRIBERY OF FOREIGN Public OfFicials IN INTERNATIONAL Business TRANSACtions and THE 1997 RECOMMENDATION ON COMBATING BRIBERY IN INTERNATIONAL BUSINESS TRANSACTIONS (Mar. 2011), available at $\mathrm{http} / / / \mathrm{www} . o e c d . o r g / d a t a s p e e d / 55 / 25 / 47438113$.pdf [hereinafter 2011 OECD REPORT].

95. TRANSPARENCY INT'L, PROGRESS REPORT 2011 - ENFORCEMENT OF THE OECD ANTIBRIBERY CONVENTION 25 (May 2011), available at http://www.transparency.ca/Reports/ CPI\&OtherReports/201107-OECD-2011-Progress_Report.pdf.

96. 1999 OECD REPORT, supra note 94, at 24.

97. See id. at 12-13, (citing Canada (Human Rights Commission) v. Canadian Liberty Net, [1998] 1 S.C.R. 626, United States of America v. Lépine, [1994] I S.C.R. 286, and R. v. Hammerbeck (1993), R.F.L. (3d) 265, 26 B.C.A.C. 1). 


\section{The 2004 OECD Report}

The OECD's second review of the CFPOA issued in 2004 disagreed that Canada's broad application of the territorial principle was sufficient:

The lead examiners are not convinced that territorial jurisdiction under Canadian law is broad enough to enable the effective application of the offence under the CFPOA. In their view an element of the offence would likely be required by the courts to have taken place in Canada. In addition, the lead examiners note that, although it has generally been the policy of Canada to only take extraterritorial jurisdiction where there has been a treaty obligation to do so, there have been exceptions to this rule. The lead examiners therefore recommend that the Government of Canada reconsider its position in this respect. $^{98}$

In March 2006, the Canadian Government provided its follow-up response to the 2004 OECD Report. Canada stated:

The Convention does not require Parties to exercise jurisdiction on the basis of nationality. Article 4 of the Convention requires Parties to review whether its current basis for jurisdiction is effective to fight corruption of foreign public officials and take remedial steps if it is not. Canada conducted such a review and is of the view that territorial jurisdiction, as interpreted by Canadian courts, is effective to fight corruption. . . . Canada's position would be reconsidered if there was evidence that nationality jurisdiction is necessary to implement the Convention effectively. ${ }^{99}$

Canada's position was that article 4(4) of the Convention is the applicable standard and that article 4(2) was not applicable because Canada does not normally assert jurisdiction on a nationality basis. ${ }^{100}$ Article $4(4)$ of the OECD Convention provides that "[e]ach Party shall review whether its

98. 2004 OECD REPORT, supra note 94, $\mathbb{\text { I }} 77$.

99. OeCD, Canada: Phase 2, Follow-Up Report on the Implementation of the Phase 2 ReCOMmendations on the APPLICATION OF THE CONVENTION AND THE 1997 ReCOMMENDATION ON COMBating Bribery OF Foreign PUBlic Officials IN INTERNATIONAL BUSINESS TRANSACTIONS, 21 (June 2006), available at http://www.oecd.org/dataoecd/5/6/36984779.pdf [hereinafter FoLLOW-UP TO 2004 REPORT].

100. Id. 
current basis for jurisdiction is effective in the fight against the bribery of foreign public officials and, if it is not, shall take remedial steps." 101

Presumably in response to the concerns raised by the 1999 and 2004 OECD reports, in May 2009, the Canadian Government introduced Bill C$31^{102}$ to amend the CFPOA (and certain other statutes). The proposed amendment would have given the Canadian authorities jurisdiction to prosecute Canada's foreign corruption offense on the basis of nationality:

4. (1) Every person who commits an act or omission outside Canada that, if committed in Canada, would constitute an offence under section 3 [Bribing a Foreign Official] - or a conspiracy to commit, an attempt to commit, being an accessory after the fact in relation to, or any counselling in relation to, an offence under that section - is deemed to have committed that act or omission in Canada if the person is

(a) a Canadian citizen;

(b) a permanent resident within the meaning of subsection 2(1) of the Immigration and Refugee Protection Act who, after the commission of the act or omission, is present in Canada; or

(c) a public body, corporation, society, company, firm or partnership that is incorporated, formed or otherwise organized under the laws of Canada or a province. ${ }^{103}$

In the Parliamentary debates on this Bill, a member of the Conservative party (which was the party in power as a minority government in 2009,104 and at the time of writing is in power as the majority government ${ }^{105}$ ) justified these amendments in the following manner:

Most of the time, these [foreign corruption] offences are committed in a foreign country. . . Nationality jurisdiction

101. OECD Convention, supra note 4, art. 4(4).

102. Canada, Bill C-31, An Act to Amend the Criminal Code, the Corruption of Foreign Public Officials Act and the Identification of Criminals Act and to Make a Consequential Amendment to Another Act, 2nd Sess., 40th Parl., cl. 38 (2009).

103. Id.

104. 40th Parliament of Canada Profile, ParLIAMENT OF CANADA, http://www.parl.gc.ca/ parlinfo/Files/Parliament.aspx?Item=8714654b-cdbf-48a2-blad-57a3c8ece839\&Language $=E$ (last visited Feb. 5, 2013).

105. 41st Parliament of Canada Profile, PaRLIAMENT OF CANADA, http://www.parl.gc.ca/ parlinfo/Files/Parliament.aspx?Item=1924d334-6bd0-4cb3-8793-cee640025ff6\&Language=E (last visited Feb. 5, 2013). 
would allow Canada to prosecute offences of foreign bribery committed outside Canada by Canadians, permanent residents of Canada and Canadian corporations without having to provide evidence of a link between Canada and the offence. This would facilitate prosecutions of foreign bribery cases. ${ }^{106}$

Bill C-31 was not was passed into law before the end of the Fortieth Parliament. ${ }^{107}$ The head of Transparency International Canada has called for the reintroduction of the Bill. ${ }^{108}$

\section{The 2011 OECD Report}

The OECD's third report on the CFPOA, issued in 2011, is more pointed in its criticism of what the OECD Working Group considers to be Canada's narrow scope of jurisdiction:

119. The lead examiners do not share Canada's view and believe that the absence of nationality jurisdiction leaves a substantial loophole in the coverage of the CFPOA, and needlessly poses a substantial hurdle to investigation and prosecution in obliging authorities to prove a 'real and substantial link' to the territory of Canada.

120. The lead examiners consider that Canada is applying an overly restrictive interpretation to Article 4(2) of the Convention... ${ }^{109}$

The OECD Working Group also emphasized that the nature of foreign corruption is that the act of bribery often occurs in the foreign country. Thus, it believes that a state must assert nationality jurisdiction to effectively combat foreign corruption. ${ }^{110}$

Assessment of Canada's arguments for not asserting jurisdiction based on nationality

As noted above, Canada contends that, because it does not regularly

106. House of Commons Debates, No. 116 (Nov. 24, 2009) (statement of Brent Rathgeber), available at http://www.parl.gc.ca/HousePublications/Publication.aspx?Docld=4254820\& Language $=\mathrm{E} \& M o d e=$.

107. House Government Bill C-31: Status of the Bill, Parliament of CANADA : LEGISINFO, http://www.parl.gc.ca/LegisInfo/BillDetails.aspx?Language=E\&Mode $=1 \& B i l l=$ C31\&Parl=41\&Ses=1 (last visited Feb. 5, 2013).

108. Pablo Fuchs, Anti-bribery Laws: The Net Tightens, Canadian CORP. Couns. Ass'N MAG., Winter 2011, at 16, available at http://ccca.dgtlpub.com/2011/2011-12-31/pdf/Antibribery_laws_Keeping_your_company_out_of_trouble.pdf.

109. 2011 OECD REPORT, supra note 94, ๆ $119-20$.

110. Id. $\ 120$. 
assert jurisdiction on the basis of nationality, the opening phrase in article $4(2)$ of the $O E C D$ Convention does not require Canada to exercise such jurisdiction. ${ }^{11}$ Rather, Canada asserts that article $4(2)$ is aimed at other states, such as those under the civil law tradition, who regularly assert jurisdiction on the basis of nationality. ${ }^{112}$

However, the literal wording of article 4(2) of the OECD Convention would suggest that the territoriality and nationality branches of jurisdiction are each freestanding requirements that are supplemented - not limited - by the additional requirement to take remedial action where necessary as set out in article 4(4).

Section 7 of the Criminal Code and Bill C-31 both demonstrate that, as a general matter, Canada "has jurisdiction to prosecute its nationals for offences committed abroad" even though it has only chosen to implement this jurisdictional reach in respect of certain behaviors. The ability to do so would appear to be sufficient to activate the requirement in the opening phrase of article 4(2). This in turn would lead to the obligation under the OECD Convention that Canada "shall take such measures as may be necessary to establish its jurisdiction over the bribery of a foreign public official ...."113

Canada also continues to claim that, given the broad application of the territorial principle, which merely requires a real and substantial link to Canada to establish jurisdiction, it has an effective regime to combat foreign corruption offenses. For example, the Canadian agencies charged with investigating and prosecuting offenses under the CFPOA, the Royal Canadian Mounted Police (RCMP) and the Public Prosecution Service of Canada (PPSC), have told OECD investigators that:

[P]olice and prosecutors are willing to pursue a case of foreign bribery with a broad understanding in mind of what amounts to a "real and substantial link" to the territory of Canada and to do so until either the Canadian courts say this is going too far, or until nationality jurisdiction is introduced into law. ${ }^{114}$

While the stated enthusiasm of enforcement officials is a positive step in combating foreign corruption offenses, it may prove inadequate when an attempt to apply the CFPOA to non-Canadian actions of Canadian nationals is challenged before the courts (as in the pending Karigar case described above).

111. Id. ๆศ 117-18.

112. Id.

113. OECD Convention, supra note 4 , art. 4 (1).

114. 2011 OECD REPORT, supra note 94, ๆ 116. 
Scenarios where Canada's lack of jurisdiction based on nationality leaves a gap

Canada is the only party to the OECD Convention not to have established jurisdiction on a nationality basis. ${ }^{115}$ Canada's territoriallylimited jurisdiction over foreign corruption offenses leaves a gap in the international foreign corruption regime. The gap almost certainly applies to conduct of Canadian nationals that occurs wholly outside Canada. There is also a gap in respect to other conduct of such nationals which does not have a connection to Canada that is sufficiently "real and substantial" -- even if there may have been some minimal connection to Canadian territory.

Many transnational corporations are based in OECD member states. A substantial portion of the bribes of foreign officials are likely to come from nationals of an OECD state, either from individual citizens or organizations based in (or constituted under the laws of) an OECD member state. ${ }^{116}$ In the states where corruption is the biggest problem, the domestic anti-corruption regime is likely to be ineffective, or possibly non-existent. This makes enforcement on the basis of nationality particularly important because the ability to prosecute the party giving the bribe will be the primary deterrent to corruption. Even if the public official in the recipient jurisdiction is subject to prosecution, deterring corruption requires the ability to take action against the payor as well.

\section{The potential for multi-jurisdictional overlap}

In certain situations, Canada's nationality gap in respect to payers of bribes could be overcome through enforcement by another state that may have a basis for jurisdiction. Particularly obvious candidates include the United States and the United Kingdom.

Under the FCPA, the United States has jurisdiction over corporations which are registered with the US Securities Exchange Commission (SEC) to issue securities. ${ }^{117}$ Thus, if a Canadian corporation was registered as an issuer with the SEC (as many are, given the importance of the US capital markets) and that corporation gave a bribe anywhere in the world to a foreign official, it would appear that the US authorities would have jurisdiction to prosecute the corporation (regardless of whether the bribery took place within US territory).

Under the UK Bribery Act, the United Kingdom has jurisdiction to

115. See FoLLOW-UP TO 2004 REPORT, supra note 99, ๆ 9; See also Andrew Thompson \& Prakash Narayanan, Canada Lags in Combating International Bribery, THE LAWYERS WKLY., Apr. 1, 2011, at 15.

116. These two attributes are the most common indicators of an organization's nationality. See CuRRIE, supra note 66 , at 346.

117. FCPA, supra note $2, \S \S 78 \mathrm{dd}-1$ (a)-2(a), 3(a). 
prosecute for failure to prevent bribery in respect of all corporations and partnerships which carry on any business in the United Kingdom. ${ }^{118}$ The UK authorities can prosecute such corporations for failing to prevent bribery if any person (including legal persons) performing services for or on behalf of the corporation bribes a foreign official. ${ }^{119}$ Examples of persons who may perform services for or on behalf of a corporation include subsidiaries, agents or employees. ${ }^{120}$ Assuming that a Canadian corporation does some business in the United Kingdom (which many do, given the close economic and historical ties between the countries), or that it is an affiliate of a UK corporation, and the Canadian corporation bribed a foreign official anywhere in the world, it would appear that, depending on the facts, the UK authorities could have jurisdiction to prosecute the corporation for failing to prevent bribery (regardless of whether the bribery took place within UK territory). ${ }^{121}$

Enforcement by US or UK authorities would be a circuitous way to combat foreign corruption by Canadian companies. Investigations and prosecutions may or may not occur depending upon a variety of factors including available resources and access to relevant evidence. This approach may also not be fully effective because such foreign states are less likely to have jurisdiction over the individual Canadian citizens paying the bribes, even where those Canadian citizens are acting as employees or agents of a corporation that is within their jurisdiction. In any event, even if other countries have the potential to fill Canada's jurisdictional gap in certain situations, this is not a persuasive reason for Canada to ignore its international obligations.

\section{LACK OF COVERAGE OF THE NON-PROFIT SECTOR}

The second key limitation in Canada's foreign corruption regime is that it appears to ignore the significant number of organizations that do not operate on a for-profit basis. There are hundreds of not-for-profit organizations or other non-governmental organizations that are active in countries grappling with poverty, political instability, and the challenges of social and economic development. Many of these countries have high Transparency International Corruption Index scores, ${ }^{122}$ and not-for-profit organizations are at risk of becoming involved in corruption activities. ${ }^{123}$

118. UK Bribery Act, supra note $3, \S \S 7(5), 8$.

119. Id. $\$ 7$.

120. Id. $\$ 8$.

121. Id. $\$ 7$.

122. See TI CORRUPTION INDEX, supra note 27.

123. See, e.g., TRANSPARENCY INTERNATIONAL UK, ET AL., ANTI-BRIBERY PRINCIPLES AND GUIDANCE FOR NGOS 7 - 8 (June 2011), available at http://www.transparency.org.uk/ourwork/publications/10-publications/128-anti-bribery-principles-and-guidance-for-ngos. 
The CFPOA bribery offense contains an element requiring the bribe to be made "in order to obtain or retain an advantage in the course of business." $" 24$ This element is significant given how the CFPOA defines "business" as "any business, profession, trade, calling, manufacture or undertaking of any kind carried on in Canada or elsewhere for profit." 125

In the Parliamentary debates when the CFPOA was being enacted, the Minister of Foreign Affairs acknowledged that it did not address not-forprofit organizations. ${ }^{126}$ However, there was a suggestion that individual transactions could be examined to determine if they were for-profit or not, rather than looking at the character of the entity involved. ${ }^{127}$ This transaction-by-transaction approach appears to be reflected in the Department of Justice's guide to the CFPOA, which states: "The Act targets the bribery by any person of a foreign public official when the transaction is for profit." 128

As of the date of writing, the CFPOA's application to potentially profitable transactions made by not-for-profit organizations has not been interpreted by the courts. However, the statutory provision focuses on business entities rather than transactions, and enforcement activities to date have focussed on business entities. This has been the case despite periodic concerns involving public officials profiting from aid or relief work for their own benefit. ${ }^{129}$

The scope of Canada's international obligations with respect to not-forprofits

Neither the OECD Convention nor the UN Convention explicitly limits their application to for-profit organizations or transactions. Both conventions refer to "business." While such references could be interpreted as suggesting that they are not aimed at non-profit undertakings, this

124. See CFPOA, supra note 1 , at 2.

125. Id. at 1 (emphasis added). See also Martin, supra note 69, at 197.

126. Debates of the Senate (Hansard), Ist Session, 36th Parliament, Volume 137, Issue 100, Dec. 3, 1998, Parliament OF CANADA, http://www.parl.gc.ca/Content/Sen/Chamber/ 361/Debates/ 100db_1998-12-03-e.htm (last visited Feb. 5, 2013) [hereinafter Senate CFPOA Hansard].

127. Id at 1540.

128. DOJ Guide, supra note 5 , at 5.

129. See, e.g., Cleaning up - Can the Global Fund to Fight Aids, Tuberculosis and Malaria Restore its Reputation as the Best and Cleanest in the Aid Business?, THE ECONOMIST (Feb. 17, 2011), available at http://www.economist.com/node/18176062; John Cook, Wyclef Jean's Corrupt Charity Is Still Very, Very Corrupt, GAwKER (Nov. 29 2011), http://gawker.com/5863554/wyclef-jeans-corrupt-charity-is-still-very-very-corrupt; New Corruption Charges against the Red Cross and Other Charities, AsIANEw.IT (Aug. 18, 2011, 3:22 PM), http://www.asianews.it/news-en/New-cormption-charges-against-the-RedCross-and-other-charities-22395.html. 
approach has not been adopted outside Canada. The Inter-American Convention does not even refer to "business," but merely to corruption in terms of providing "advantages" in exchange for acts or omissions of a government official. ${ }^{130}$

The full title of the OECD Convention is the "Convention on Combating Bribery of Foreign Public Officials in International Business Transactions." Article 1(1) establishes the requirement to criminalize the act of bribing foreign officials in the following manner:

[E]ach Party shall take such measures as may be necessary to establish that it is a criminal offence under its law for any person intentionally to offer, promise or give any undue pecuniary or other advantage, whether directly or through intermediaries, to a foreign public official, for that official or for a third party, in order that the official act or refrain from acting in relation to the performance of official duties, in order to obtain or retain business or other improper advantage in the conduct of international business. ${ }^{131}$

Canada's position is that the OECD Convention is aimed at for-profit business. ${ }^{132}$ It has also attempted to focus on transactions rather than organizations: "Business transactions imply a profit motive. Therefore, the Convention applies to transactions that are carried on to generate some form of profit." $" 133$ The OECD Working Group on Bribery takes the opposing position.

\section{The 2004 OECD Report}

In its second report on CFPOA, the OECD Working Group observed that the OECD Convention does not distinguish between for-profit and not-

130. Inter-American Convention, supra note 6, art. VII.

131. OECD Convention, supra note 4, art. 7 (emphasis added). Cf. UN Convention, supra note 8, at arts. 16(1), 26(4) The counterpart provision in the UN Convention is article $16(1)$, which is very similar to article 1(1) of the OECD Convention (including the references to business), except that there is no reference to "any person". Article 16(1) of the UN Convention is nonetheless broadly phrased, because the wording requires the state to criminalize the act of bribing a foreign official without any reference to the type of natural or legal person that perpetrated the act. Article 26(4) of the UN Convention also requires that states shall ensure that legal persons are subject to effective and dissuasive sanctions. The Inter-American Convention counterpart is article VI(1), and is also broadly worded.

132. Senate CFPOA Hansard, supra note 126, at 28 (statement of Mr. Axworthy, Minister of Foreign Affairs).

133. FOLLOW-UP TO 2004 REPORT, supra note 99, at 20. 
for-profit entities. ${ }^{134}$ It recommended amending the definition of "business" in Section 2 of the CFPOA to remove the for-profit requirement. ${ }^{135}$ The report concluded that this was a significant limitation having regard to Canada's large non-profit sector (which consisted of 180,000 organizations employing $10 \%$ of the Canadian workforce as of 2001). ${ }^{136}$ It stated: "[T]he explanations of the Canadian authorities did not convincingly dispel concerns about the possibility of the non-application of the CFPOA to nonprofit companies, and the lead examiners believe that such a gap in the CFPOA would result in the non-coverage of a sizable sector in the Canadian economy." 137

Even the possibility of classifying individual transactions as "for profit" concerned the OECD Working Group. It noted that "the 'for-profit' requirement might enable for-profit companies to escape the application of the CFPOA in certain circumstances by describing the transactions in question as not for profit." 138

\section{The 2011 OECD Report}

The 2011 OECD Report largely repeated the criticisms of the 2004 OECD Report. As additional support countering Canada's "for profit" only position, the OECD Working Group pointed out that Article 1 of the OECD Convention states: "Each Party shall take such measures as may be necessary to establish that it is a criminal offence under its law for any person intentionally to offer, promise or give any undue pecuniary or other advantage." 139

Through the use of the "any person" terminology, the OECD Working Group is of the view that the OECD Convention is to be applied broadly, without regard to the profit motives of the organization giving a bribe. In addition, the 2011 OECD Report pointed out that Canada is the only state that has included a "for profit" requirement in the bribery offense. ${ }^{140}$

During the investigation leading up to the 2011 OECD Report, the OECD investigators met with representatives from the RCMP, the PPSC, Department of Justice, the Department of Foreign Affairs and International

134. 2004 OECD REPORT, supra note 94, ๆ 66. The 1999 OECD REPORT did not address the non-profit limitation in CFPOA.

135. Id. $ๆ 70$.

136. $I d . \rrbracket 69$.

137. Id. $₫ 70$.

138. Id.

139. 2011 OECD REPORT, supra note 94, ๆ 21; OECD Convention, art. 1 (emphasis added).

140. 2011 OECD REPORT, supra note 94, ๆ 15. In response, Canada again relied on the inclusion of the term "business" in the title and the text of the OECD Convention to imply a "for profit" requirement into the Article 1 obligations. See id. ๆๆ 23-24. 
Trade (DFAIT), and the Canada Revenue Agency (CRA). ${ }^{141}$ Among these Canadian authorities there was disagreement as to whether the "for profit" requirement would operate on a transaction-by-transaction basis (the transactional approach) or would depend on the nature of the organization involved (the organizational approach) ${ }^{142}$ This disagreement between key government agencies fortified the OECD Working Group's view that the "for profit" requirement in the CFPOA should be amended, given the possibility that uncertainty could undermine the deterrent effect of the law and/or hinder enforcement. ${ }^{143}$

Assessment of Canada's arguments regarding the "for profit" limitation in the CFPOA

Some Canadian enforcement officials take a broad view of the potential application of CFPOA, notwithstanding the Canadian government's formal position. For instance, "[a] representative of one of the RCMP International Anti-Corruption teams stated that the RCMP will investigate allegations of foreign bribery without considering the impact of the 'business for profit' requirement, unless the courts determine what consequences, if any, the requirement has on the scope of the CFPOA." 144

However, enthusiasm on the part of enforcement officials is not a substitute for possible legal limitations that may be determined by courts which must construe criminal statutes strictly in favor of the accused. ${ }^{145}$ At a minimum, the "for profit" reference in the CFPOA definition of business must have some meaning and will likely require a choice to be made between the organizational and the transactional interpretation.

As a general matter, it is possible for non-profit organizations to engage in business transactions including purchases and sales of goods and services. If the Canadian courts interpret the "for profit" requirement of the CFPOA on the basis of the "organizational approach," then the substantial number of Canadian enterprises in the not-for-profit sector would effectively be exempted from the CFPOA. ${ }^{146}$ This could result in the odd situation where for-profit organizations that may be small and in some cases not operating profitably, could be subject to investigation and prosecution

141. 2011 OECD Report, supra note 94, ๆ 1, Annex 2.

142. Id. ๆी $19-24$.

143. Id. ๆๆ $21-22$.

144. Id. ๆ 20.

145. See, e.g., RUTH SUlLIVAN, STATUTORY INTERPRETATION $223-25$ ( $2 \mathrm{~d}$ ed. 2007).

146. As discussed earlier, other states such as the United States and the United Kingdom have expansive approaches to jurisdiction. Those other states may have jurisdiction over the actions of Canadian not-profits in certain situations. However, for the same reasons discussed in respect of nationality-based jurisdiction above, reliance on foreign states is not an adequate substitute for appropriate enforcement action by Canada. 
while sizeable not-for-profits which transact on a very significant scale internationally would be ignored.

The alternative possible interpretation of "for profit" is the "transactional approach." If the courts look at the nature of the transaction to determine whether CFPOA applies, this could be problematic for two reasons. The first concern is that the transactional approach would introduce substantial uncertainty into the law. The characterization of individual transactions could be a very fact-driven process, involving a wide range of evidence relating to the broader context, economics, and motives for the transaction. The second disadvantage is that the transactional approach could permit both non-profit and for-profit enterprises to engage in bribery for some types of activities. Possible examples include transactions that may not be directly motivated by profit or may not be directly profitable as implemented. Bribery would then become permissible under Canadian law for certain types of activities that were sufficiently removed from profit generation.

Some Canadian authorities have stated that they will apply either the organizational approach or the transactional approach, as the circumstances require. ${ }^{147}$ There are four possible types of transactions to consider: (i) profitable transactions by a for-profit entity; (ii) transactions that are unprofitable or unrelated to profit by a for-profit entity; (iii) profitable transactions by a non-profit entity; and (iv) transactions that are unprofitable or unrelated to profit by a non-profit entity. Presumably the "either organizational or transactional approach" would mean that everything done by a for-profit organization (categories $i$ and ii) is captured by the CFPOA, and that for-profit transactions by a not-for-profit organization (category iii) would also be captured (and only category iv would be beyond the statutory reach). However, this approach may not be accepted by a court interpreting a criminal statute which, as noted above, must be construed strictly in favor of the accused. ${ }^{148}$

In our view, a Canadian court is likely to select one of the organizational or the transactional approaches, rather than the either/or option. The organizational approach seems most likely to be adopted by a court. Aside from the aforementioned complexities and uncertainty that would arise from examining individual transactions, section 2 of the CFPOA, which is the origin of the "for profit" requirement, speaks in organizational terms (i.e., the phrase "profession, trade, calling [...] for profit" refers not to individual activities or transactions, but rather to the nature of the entity as a whole). ${ }^{149}$ If Canadian courts do adopt this

147. 2011 OECD REPORT, supra note $94, \$ 24$.

148. SULLIVAN, supra note 145 , at 223-25.

149. While the phrase "undertaking of any kind carried on in Canada or elsewhere for profit", on its own, could mean a single transaction or other activity, the term undertaking is often used in Canadian legislation to refer to business entities rather than 
interpretation, the OECD Working Group concerns about the coverage of CFPOA will continue to exist.

\section{CONCLUSION}

Enforcement of Canada's anti-foreign-corruption regime had a slow start but is becoming increasingly vigorous and higher profile. It is facilitated by a broad approach to territorial jurisdiction based on a "real and substantial link" test that applies to some situations where conduct occurs partly within and partly beyond Canadian borders.

However, the CFPOA has two important limitations. First, Canada does not assert jurisdiction over foreign corruption offenses on the basis of nationality. Second, the application of the CFPOA appears to be limited to "for profit" businesses. Among the signatories to the OECD Convention, these exceptions are both unique to Canada. Both of these limitations also appear to be in breach of Canada's obligations under the OECD Convention and have raised international concern.

The courts may have the opportunity to clarify these limitations sooner rather than later since the Canadian authorities charged with investigating and prosecuting bribery offenses have numerous foreign corruption investigations in progress. The authorities have also expressed their willingness to test the scope of CFPOA in these areas and to let the courts decide whether they have gone too far. The defense in the upcoming Karigar prosecution will be the first important test.

\section{ADDENDUM}

Prior to finalization of this article for publication, the Canadian Government introduced proposed amendments to the CFPOA. ${ }^{150}$ They will add nationality jurisdiction and address the not-for-profit issue noted in this paper, as well as removing the exemption for facilitating payments, creating a new books and record offense, and raising the maximum penalty to 14 years imprisonment. ${ }^{151}$

In addition, a fourth CFPOA case was brought against Griffiths Energy. ${ }^{152}$ It pleaded guilty and was fined $C \$ 10$ million in respect of a $C \$ 2$

transactions. In addition, the "associated words" rule of statutory interpretation (noscitur a sociis) (see SULLIVAN, supra note 145 , at 175 ) indicates that the preferred meaning of "undertaking" should accord with the other entity-oriented terminology in the definition of business.

150. Canada, Bill S-14, An Act to Amend the Corruption of Foreign Public Officials Act, 1st Sess., 41 st Parl., (2013).

151. Id.

152. Her Majesty the Queen v. Griffiths Energy International (2013), E-File No.:CCQ13GRIFFITHSENER, Action No. 130057425Q1, (Can. Alta. Q.B.). 
million bribe paid to the wife of the Chadian ambassador to Canada in respect of oil and gas development agreements in the Republic of Chad. ${ }^{153}$

153. See generally McMillan LLP, CoOPERATing Firm Agrees to Penalty Equal to 5 TIMES THE AMOUNT OF FOREIGN BRIBE (2013), available at http://mcmillan.ca/cooperatingfirm-agrees-to-penalty-equal-to-5-times-the-amount-of-foreign-bribe. 
